\title{
DREAMS AS COMMUNICATION METHOD BETWEEN \\ THE LIVING AND THE DEAD \\ ETHNOGRAPHIC CASE STUDY FROM SLOVAKIA
}

\section{GABRIELA KILIÁNOVÁ}

The paper discusses dream narratives concerning deceased persons who were close to narrators. The author argues that the attitudes towards this type of dream narratives are specific in traditional as well as in modern society: such dreams are often interpreted as communication method between the worlds of living and dead people who need each other. The paper focuses on a local community in Western Slovakia and deals with the following questions: (1) to what degree has dream experience been integrated in public life of the local community and what are the conditions of this integration; (2) how the dream narration is treated in the private and public discourse; and (3) what are the interpretations of the dreams. The author is interested in the changes of interpretations of the dreams that have currently occurred as a result of postsocialist transformation processes after 1989.

Keywords: dreams about the dead, communication with dead, dream narrative, interpretation of dream, Slovakia, post-socialist period.
$V$ prispevku so obravnavane sanjske pripovedi o pokojnih, ki so bili blizu pripovedovalcem. Avtorica meni, da so odnosi do takšnih sanjskih pripovedi posebni v tradicionalni in sodobni družbi: sanje so pogosto interpretirane kot metoda komunikacije med svetovoma živih in pokojnih, ki potrebujejo drugi druge. Članek se osredinja na lokalno skupnost na zahodnem Slovaškem in obravnava naslednja vprašanja: 1 . do katere stopnje je sanjska izkušnja vključena v javno življenje lokalne skupnosti in kateri so pogoji takšne vključenosti; 2. kako je sanjska pripoved obravnavana $v$ zasebnem in javnem diskurzu; in 3. kakšne so interpretacije sanj. Avtorico zanimajo spremembe $v$ interpretacijah sanj, ki so nasledek postsocialističnih procesov transformacije po letu 1989.

Ključne besede: sanje o pokojnem, komunikacijas pokojnim, sanjska pripoved, interpretacija sanj, Slovaška, postsocialistično obdobje.

\section{INTRODUCTION}

Dreams about deceased ancestors and departed relatives or friends represent a special category of dream experience in European and non-European societies. Research findings have demonstrated a rather high frequency of their occurrence. Anybody can have this experience; it is not limited to such "experts" as shamans, healers, or priests. In various cultures, dreams about ancestors or deceased relatives have been perceived as a means of communication between the living and the dead to convey messages, warnings, or explanations, or to ask for help (see, e.g., Jedrej 1992: 114, 121; Shaw 1992: 42-45; Hasan-Rokem 1999: 216 ff.; Pócs 1999: 29 ff.; Tiukhteneva 2007: 43 ff.). Here, by dreams I understand a complex experience including images, sounds, touches, or other sensations that people experience during sleep. Dreams are subjective experiences that ". . . are necessarily transformed into words in order to turn them into meaningful communication not just among individuals, but also between the dream- 
ing individual and her/himself" (Hasan-Rokem 1999: 214). In other words, we cannot examine dreams as such because we cannot observe them, but we can investigate reports about subjective experiences (Jendrej 1992: 101).

My study focuses on dream narratives about the dead as well as on the process of narration and transmission in a particular community in Slovakia. By dream narratives, I understand stories that usually communicate the content of a dream as well as its interpretation and "implementation." This means that dream narratives might inform people about events that followed after the dream occurred, about fulfilled or unfulfilled predictions, or implications of the dream for a dreaming person as well as for his or her family, friends, or relatives. As Hasan-Rokem notes, dream narratives are mostly descriptive and oriented toward the past, unlike dream interpretations that might be prescriptive and future oriented (1999: 219).

I have investigated dream narratives in modern European society, but it is necessary to specify the particular type. Social scientists have paid sufficient attention to the various conditions of modernization processes in various European countries, including diverse timing as well as political, economical, cultural, and ideological settings. ${ }^{1}$ In Slovakia these processes have taken place for approximately two centuries. They can be divided into two stages: the first wave of modernization occurred from the beginning of the nineteenth century to the beginning of the twentieth century, and the second wave has taken place roughly since the 1950s (Lipták 2000: 284-286; Mannová-Holec 2000: 185-234). The second wave of modernization occurred under the conditions of a totalitarian regime, when free public discussions of various social problems were rather restricted. As a result, many issues including death and dying were taboo, whereas conservative and traditional phenomena, attitudes, and values were supported in mundane culture.

Currently, Slovakia is open to globalization processes that are creating new tendencies. On the one hand, they support the transmission of worldwide phenomena primarily related to the economic and cultural dominance of North America and western Europe. On the other hand, the current social changes have been caused either by the process of globalization or by the transformation processes in politics, economics, and culture that have taken place in Slovakia since 1989. Investigation of those processes reveals the heterogeneity of local settings with all their contradictions and diver-

1 By "modernization" I understand long-term processes that have engendered fundamental changes in people's everyday lives, attitudes, and values. On the one hand, this term denotes technical, technological, economical, political, and organizational changes related to industrialization and urbanization. On the other hand, one can observe a shift from traditional culture to modernity accompanied by processes such as rationalization, differentiation, individualization, secularization, migration, disengagement of family bonds or kin affiliations, and so on. Like other researchers, I do not understand modernization as a linear evolution, but as a development that may include recurrent and complementary processes. Although modernization processes are global, this does not mean that they automatically cause homogenization processes (Martin 1999: 27-33; Miller 1995: 3-4). 
sity. My case study therefore pays attention to both the description of the local cultural context and the timing of the local changes.

During my research I focused on obtaining dream narratives as oral stories. However, I was also interested in the process of narration; thus I also investigated ways of sharing dream experiences. Finally, I investigated the transmission of narratives in the local community in connection with the social context: I paid attention to the narrator as well as the audience with regard to social groups in the locality.

The research indicated that the dream experience in modern society is usually presented in personal accounts related privately in a narrow circle of relatives and friends (Tedlock 2003: $106 \mathrm{ff}$.). It is therefore informal communication in the private sphere; henceforth I use the term "private talk." During my research I concentrated on whether dream narratives could be integrated into public aspects of social life in a community and become part of public formal communication. If so, under what conditions does this take place and how are the narratives evaluated in the context of public discourse? In this case I speak about transmission of dream narratives by means of public talk. ${ }^{2}$

I paid attention in particular to alterations of dream narratives that might have taken place after the major political change of 1989 as a result of the post-socialistic transformation. At this period, the taboo on a range of topics related to death and "irrational" beliefs or experience was over: they became an object of public interest. I therefore investigated whether the major changes influenced alteration of the discourse about death and dreams in the local community.

\section{MOTIVATION FOR SELECTING THE RESEARCH TOPIC}

My interest in dreams about the dead resulted from research that I have conducted for several years on funeral rites in the village of Závod in western Slovakia. I investigated the practice of funeral rites in this local community, which underwent a post-socialistic transformation after 1989. This historical process has changed the social, economic, and cultural conditions in Slovakia as well as in other countries of the former East Bloc. I investigated the possible influence of this development on changes in funeral rites and examined a relatively broad range of practices and beliefs connected with death. Dreams about ancestors, deceased friends, and relatives played a rather significant role in these phenomena. Most of the informants, including people that explicitly called the interpretation of dreams a "superstition," admitted that dreams about the dead belong to a specific category. Such dreams might be regarded as a specific communication method between the living and the dead-between two related worlds that need each other.

2 I have borrowed the terms "private talk" and "public talk" from Herdt (1987), but I modified them in line with the specific features of my research. 
Another reason why I chose this topic was connected with a general change in social discourse about dreams that took place in Slovakia after 1989. It is necessary to note that, unlike the situation in the US and western Europe, in socialist Czechoslovakia in the second half of the twentieth century neither scholarly research nor public discussions about dreams were possible. Dream narratives as well as theories explaining dreams or practices connected with dreaming had no place among the appropriate or required research topics in ethnology or social anthropology during the socialist period. Thus research on dreams became a new professional challenge for me.

\section{FIELD SITE AND FIELDWORK}

My case study is based on ethnographic research in the village of Závod, located fortyfive kilometers from Bratislava, near the border between Slovakia and Austria. In the context of Slovakia, the village is not a large settlement. At present there are 2,750 people living there. It was only the second wave of modernization in the beginning of the 1950s that changed this agrarian village into a rural locality near a powerful industrial center (Bratislava), where the employment structure has changed to a great extent. ${ }^{3}$ Since the end of the 1950s, the way of life there has been influenced by extensive migration in search of work. ${ }^{4}$ Thus the local culture was opened to modernization trends. ${ }^{5}$ Despite this, even at the end of the twentieth century I could have observed various phenomena of traditional culture characteristic of the local way of life. Such a persistence of traditional elements might have been a result of the specifics of modernization under the totalitarian regime: as already mentioned, some traditional phenomena may have been preserved because, paradoxically, they could not be publicly discussed (e.g., cultural phenomena associated with spiritual life or family customs related to religious rituals such as baptisms, weddings, funerals, etc.).

In some sense, Závod differs from many Slovak villages, which are often heterogeneous in terms of religion: almost all of its inhabitants are Roman Catholics. According

3 In the second half of the twentieth century, the employment structure dramatically changed. There was a massive move of the working population from agriculture to industry. In 1957 under political pressure a collective farm (Jednotné rolnicke družstvo, or $J R D$ ) was established in the village; this was the second attempt. Roughly one-quarter of the village's working population continued to work there, whereas there-quarters were employed in industry and services in nearby towns or even distant regions (e.g., in the Czech Republic). When the collective farm went bankrupt, only $2.5 \%$ of the working inhabitants remained in agriculture. Most of the inhabitants are employed in industry and services outside the village (64.3\%). The number of employees in local services, companies, schools, healthcare, and municipal administration has slightly increased (17.8\%).

4 For instance, one-week or two-week absences of men or single women that worked in industry in distant regions were reflected in changes in social and family life.

5 In the 1960s there was a construction boom in the village that significantly changed the lifestyle, organization of family life, relationships in nuclear families and among kin, and so on. 
to the official statistics, there are no non-believers in the village. The Catholic Church has maintained an important position there for a long time and has been strongly supported by the inhabitants despite the secularization processes in the twentieth century. In the second half of the twentieth century, when the political regime of socialist Czechoslovakia systematically limited the activities of the Christian churches and thus tried to force people to abandon their faith, religious life in Závod was relatively active. However, during this period most people did not declare their faith in the census, and therefore the statistics do not indicate the exact number of Roman Catholics (or nonbelievers) in Závod during the socialist period. However, affiliation with the Catholic Church can be traced in some recorded activities and the behavior of the inhabitants. ${ }^{6}$ After the political changes in 1989, the importance of the Catholic Church in public and private life even increased. The inhabitants openly declared their religion and participated in the church's activities even more. Thus the village followed the general social trend in Slovakia. ${ }^{7}$

Since 2001 I have regularly gone to Závod for one-week or two-week fieldtrips to study funeral rites. However, I had already conducted research in the locality since 1988. At that time I concentrated on topics such as work migration and traditional cultural phenomena. I started to investigate dreams in particular in 2007, and continued in 2008 and 2009. While doing this research I was helped by Anna, ${ }^{8}$ a seventy-nineyear-old local woman. She has lived in Závod all her life and knows almost everybody in the village. She has participated in the activities of the local Catholic parish for more than fifty years and is respected by most of the inhabitants. Anna arranged interviews for me with people that were known as narrators of dreams. She participated in most of the interviews together with her friend and neighbor Hermína, an eighty-year-old women that was born in Závod and lived there most of her life. Thus during the narration Anna and Hermína created an impression of a natural audience that produced an atmosphere of trust and security on.

However, I was aware of the fact that the relationship with Anna and her assistance during the fieldwork could create some limits or obstacles in the communication

6 For instance, the village chronicle, church records, and research data demonstrated that religious rituals such as baptisms, weddings, or funerals were still practiced after 1948, when the communist government came to power, despite strong pressure from the state. People still participated in organized pilgrimages and other church activities; they read and distributed religious literature, and so on.

7 According to the statistics, the percentage of believers in the entire population of Slovakia increased from $72.8 \%$ in 1991 to $84.1 \%$ in 2001. The percentage of members of the Roman Catholic Church increased from $60.4 \%$ in 1991 to $68.9 \%$ in 2001; the percentage of members of the Lutheran Church increased from 6.2 to $6.9 \%$; the percentage of members of the Eastern Orthodox Church increased from $3.4 \%$ to $4.1 \%$; and the percentage of the members of the Reformed Christian Church increased from 1.6\% to 2\% (Population and Housing Census in Slovakia in 2001. Retrieved 20 June 2008 from http://www.statistics.sk/webdata/slo/scitanie/tab/zu.htm) On the "religious turn" in post-communist Slovakia, see Podolinská (2010).

8 All names of research participants were changed to protect their privacy. 
with the locals. The circle of my informants might mostly be chosen from the circle of Anna's friends and relatives, and it might omit some groups or individuals in the locality. Therefore I also contacted respondents directly, without Anna's assistance, using suggestions and information from any inhabitants, local authorities, the local priest, and so forth.

I had almost no difficulties in obtaining accounts of dream experiences from people. After initial brief questions, they usually started to describe their dreams about ancestors or deceased relatives and friends. The conversations might have taken place on streets, on a bench near a church building, in a shop, or in houses during visits. It seemed that my questions never surprised people, nor did they wonder about them.

The informants that spontaneously responded to my questions, however, were almost without exception women. They belonged to different age categories and different social groups. So far I have conducted semi-structured interviews with twenty-four women. The youngest woman was thirty-two years old and the oldest one was eighty years old. All of them were Christian believers and participated in the activities of the local Catholic parish. Most of them belonged to a social group that can be described as middle class in the context of the locality. Two women, however, had higher positions in the local community, and three other women had rather low social status.

Men were usually unwilling to talk about dreams, although they participated in the interviews with women as listeners. They claimed that they did not have any dreams or that they never remembered them. Only three men have told me dreams so far. One of them was Pavol, a thirty-eight-year-old local entrepreneur that already cooperated with me during my previous research. The second story was told by Imrich, a seventy-year-old middle-class retiree that participated in local parish activities together with his wife, daughter, and her family; it was Anna again that arranged the interview with Imrich. Finally, dreams about his deceased grandfather were told by Andrej, a seventy-year-old middle-class retiree. He recalled his dreams while I was talking with his wife Helena.

However, all of these men emphasized that their dreams about the dead were "common" dreams: they did not offer any warnings or announcements. The dead appeared in those dreams as though they were alive; most often they were doing some work, sometimes together with the dreaming person. Imrich claimed that people should not believe in dreams because it would be a superstition. Nor did Pavol believe that dreams could be meaningful. Nevertheless he assumed that the older generation (e.g., his mother) may have understood some dreams as prophesies.

I presume that the difficulty with obtaining dream narratives from men is related to the corresponding discursive frameworks. On the one hand, there is no reason to doubt the claims of my male informants that told me that they did not remember dreams or were never interested in this issue. On the other hand, however, it is necessary to take into consideration the fact that people in the local community perceive 
dreams about the dead as personal experiences often connected with one's private life, family, relatives, or friends. Thus reports about dreams are transmitted by means of narration among family members or friends; that is, within the framework of private talk. Thus I assume that men usually had trouble sharing their private experience with a woman that was, in addition, a researcher. Research data obtained from the interviews with women demonstrated that during the period investigated at least four men dreamed specific dreams about the dead.

\section{DREAMS ABOUT THE DEAD AND EMIC DREAM THEORIES}

The dreams about the dead in Závod can be divided into several groups. The first group includes dreams about announcements of death made by ancestors or relatives to a dying person or his or her family. The local parish clerk Helena, who has been my informant for several years, told me the following story:

It was my mother's dream... . She was already ailing and I brought her some dinner. When I brought her the dinner she told me: "You know what, your father came to me and told me: Vilma, prepare yourself, I'm coming for you ... ." And when I came the next day, she said:

"Helena, your father was here again. And he told me: Vilma, prepare yourself, I will come for you soon.". . . She was not very ill. She was an old woman, eighty years old then, so I assumed that it was just a dream, it might have been true though, but the doctors didn't tell me that she was that ill. Then I told my brother, he was taking care of her: . . "You know what, Jozef, she shouldn't go to the other world without care, so let's call the priest.". . .

Then the priest came... I was with her and she said:

"I don't know, but I hope your father will come for me." We were really astonished by that, ... somehow we didn't want to admit it; and it was on a Thursday night, and on Friday night she died.

The second group consists of dreams in which deceased persons contact the living to announce their needs and demands. They can appear in a dream and a dreaming person might guess what they need from their signs and gestures. Or they might explicitly say what they need or what they require. A shop assistant named Jarmila had such a dream. She told Anna and me about it when we were visiting her in the shop.

Jarmila: I'll tell you, it happened to me, when my brother died...

GK: How many years ago did it happen?

Jarmila: Eight years [perhaps]. And after the funeral [she dreamed that] he stretched out his hand and said "Give me that!" He still needed something. And we didn't know what he was asking for; it might have lasted 
for a week. [Finally] we put a crucifix on the ground near his coffin and after that we weren't disturbed anymore.

GK: Was it a sign from him?

Jarmila: Yes. That he needed something there.

(Note: Jarmila's brother died tragically. The police brought his body in a closed coffin and his family was not permitted to open it. Jarmila claimed that for this reason they did not realize that he did not have the crucifix in his hands as was required by the local funeral rite.)

The third type of dream is related to the satisfaction or displeasure of the dead caused by their relatives' behavior. In Terézia's dream her mother criticized the state of her parents' house.

Our mother was dead and we left ... our parents' house to the oldest sister, that is, to her son. Two or maybe three years had passed and he didn't do anything with it. . . And she came dressed in a white skirt like women used to wear in the village before, you know, she came in a white skirt like that, I still can see it clearly. She said to me: "And what are you waiting for with that house, are you waiting for it to fall down on your heads? Why don't you do something with it!" And I told her: "Mom, I don't care at all about your house. We left it to Radko and he doesn't do anything with it, what can we do about it. I suppose you don't want me to do something about it, to meddle in it, I'd be in trouble then."

Anna, [turning to Anna who was present during the interview] since then I've never dreamed about her.

G.K.: Really?

Terézia: Well. My mom never came again.

(Note: Anna commented that, if one talks with a deceased person in a dream, he or she will never come again.)

The dreams of the last group refer to appearances of deceased relatives, friends, or acquaintances that tell about their condition after death. The bereaved expect the occurrence of such dreams during the first months or first year after the funeral. Anna dreamed about her aunt and uncle, whom she was very close to:

They lived in that house in the forest and I used to visit them and lived there for a month or two; we loved each other: they loved me and I loved them. Well, both of them are now dead and I dreamed about them. They were clean and prepared. We didn't talk. I saw both of them in a big garden. It was green and beautiful and I saw them there. I've already said that it's a good sign if the dead are clean and are in a good environment, it means they're not damned. When I see them in this way, nice and clean. 
My informants were mostly familiar with these types of dreams. They regarded them as possible, although unusual, phenomena. Most of the informants were also aware of the basic interpretative frameworks of dreams about the dead. They knew what such dreams might probably mean and how they should be explained. They acquired this knowledge from local tradition, which was transmitted orally by means of dream narratives.

I observed that people in the village also use books on dream interpretation. During the totalitarian regime these books could not be published in Czechoslovakia, with the exception of the brief more liberal period during the late 1960s. This was probably why I found only one old publication in Závod that has been used until today (Krátky 1969). At present the book market in Slovakia offers approximately ten books on dream interpretation in Slovak or Czech. Most frequently women mentioned the dream interpretation book by Vilma Jamnická (2001); many of them owned it (the book became popular due to its author, a well-known Slovak actress). However, almost all women declared that they never use such books to explain dreams about deceased ancestors, relatives, or friends: the books are inappropriate for such dreams. Many informants condemned the use of these books in general: they regarded it as a superstition or even a sin.

People sometimes could not answer my questions about the origin of dreams; they could not explain how one can see, feel, or talk with the dead. Most of the answers were vague. Only a few of the informants had clear ideas how and why people dream. Emic theories concerning dreams as communication between the living and the dead in Závod are based on Catholic beliefs concerning the afterlife, hell, heaven, and purgatory. Dreams, especially those announcing death, have been described as messages from God. According to the informants, God warns people when something is going to happen.

The second explanation of dreams' origin was grounded in Catholic beliefs concerning the souls of the dead, the afterlife, and the existence of purgatory. In light of these beliefs, dreams about the dead are regarded as messages from souls in purgatory. The souls of the dead appear in dreams of the living and bring them messages about the dead, or about future events and people's fates. This opinion was expressed by my assistant Anna, her friend Mária, and many other female informants. Mária explained that the dead in the other world could know everything and therefore could come and warn their descendants:

Well, ... they say, don't they, that the dead know everything. How people live in the family afterwards, if they argue about the inheritance, the mother or father knows everything and they suffer a lot from this.

There were also other explanations of why people dream. For instance, according to Ján, Mária's husband, if the bereaved thinks about the deceased person a lot, then the deceased will appear in a dream. Likewise, if one meets a person during the 
day, that person might appear in a dream afterwards. Mária attentively listened to her husband's explanation and admitted that such an interpretation might be correct. She believes that dreams might come from different sources. Mária misses her deceased mother very much; she often thinks of her, and this is a possible explanation of why she has frequently had a recurring dream about her mother. However, this dream does not offer any message because Mária sees her mother in her house, busy with daily tasks. The dream is a pleasant experience for Mária and alleviates her grief.

\section{DREAM NARRATIONS AND FOLLOWING PRACTICES}

For the most part women as well as men told their family members about their dreams the morning after the dream occurred. Narration of the dream usually implied its interpretation. The narrator and audience considered the possible meaning of the dream or discussed its consequences. This interpretation process could continue in a small circle of friends, acquaintances, or colleagues. The dreaming person together with the audience tried to determine and elicit the meaning of the dream in a dialogue. A very similar process of dream interpretation was described, for instance, in dreamwork groups in the United Kingdom in 1989 and 1990 (Edgar 2000: 13 ff.).

If there was some kind of demand in the dream, it was told to the relatives or people concerned. Dreams might also be told to friends and colleagues, mostly in the morning or during the days immediately after they occurred. As a rule, the communication took place within the framework of private conversation: narrators told the dreams either to a person or group of persons whom they regarded as close and reliable. Previous research has shown that the dreams were told most frequently by women to other women (to friends and coworkers). If the dreams were told in groups, such groups were homogenous; they consisted only of women.

However, private talk and public talk could overlap in the locality. For instance, once during a shift change at the shop a shop assistant told her colleague that she had to go to the cemetery instead of going home directly. The previous night she had dreamed that she was gathering mushrooms with her deceased husband. He thereby "reminded" her of him and she had to light a candle on his grave and pray for him. The two friends talked about the dream in the presence of the customers (about eight local inhabitants), who listened to their talk. Two of them then commented on the dream narrative.

In some specific cases, people tried to share their dream experience in public talk with as many listeners as possible. To illustrate, Peter, a man who was over forty years old, divorced, and childless, lived with his parents. He committed suicide. Peter's father claimed that his son was driven to this desperate step because he had been fired. People from the village discussed this tragic incident and wondered whether Peter's 
relatives or friends could have been responsible for his suicide.

After Peter's funeral, his mother, brother, and sister-in-law dreamed many dreams. His mother dreamed the first dream after the family removed the flowers from Peter's grave. The local custom requires that flowers given by people during the funeral be left on the grave for six weeks. However, Peter died in the summer; it was very hot weather and the family removed the wilted flowers early. During the night Peter appeared to his mother and looked silently at her. She interpreted the dream as a reproach for removing the flowers from the grave early.

Peter's mother's second dream occurred soon after the funeral. She saw him as a child wearing the ceremonial frock that he wore for his first communion. Because he appeared nice and neat, the dream meant to her that "it is probably better now." According to Catholic belief, suicide is a serious sin. Thus Peter's mother and the entire family were afraid that Peter would be damned forever, and that he would remain in hell. After the second dream, his mother prayed for him and asked him to appear and to let her know how he was. Soon after that the third dream occurred. Peter was lying in the garden on the spot where he committed suicide. The mother and son talked in the dream:

"Peter, tell me, where are you. Are you in heaven?" And he said: "No, I am near hell." But we never heard about such a description, [it was] either purgatory or hell. And I . . talked about it with our priest and he said-yes, purgatory is near hell.

The message for Peter's mother about the place of his soul's destination indicated that the road to his salvation was open. He was not in hell but in purgatory, and could be helped.

In her fourth dream, Peter's mother talked with him again. She saw him in a big house. When she asked what kind of people lived there with him, he said that there were both good and evil people in the house. Peter also appeared in a dream to his sister-in-law and said that he wanted his grave to be neat. His brother dreamed that Peter asked for something without words. He appeared in a dream to the other brother and informed him that their parents had cut down the apple tree on which he hanged himself. When his brother asked his parents about it, he was told that they had indeed recently cut the tree down.

After every dream, Peter's mother prayed more intensely every day. The entire family participated in repeated masses for the dead. The dreams about Peter and the subsequent actions of the family were discussed by his mother and her neighbors or acquaintances over and over again after the church services and occasionally on the streets or in other places. Thus many of my informants knew about them even several years after Peter's death. I assume that by means of dream narrations Peter's mother conveyed specific messages to the local community, either consciously or unconsciously. She informed them that, despite his deadly sin, Peter was not in hell and there was hope for salvation. 
She also communicated what his family members were doing for Peter's salvation, how they assisted him, and how properly all of them performed their duties.

I have just mentioned the actions that could follow after dreaming about the dead. The appearance of the dead usually serves as an impulse for the bereaved to pray (the dead are reminding people of themselves), to make offerings for a mass, to give alms to the poor (e.g., to local Roma families), or to give money to the church. If the dream conveys a message about the impending death of a person, the family should take better care of that person. If this person is old or ill, the family should call a priest and all the proper church rites for the dying should be performed. If the message is different-for instance, if the deceased did not have a crucifix in the coffin-it would immediately be placed on the ground near the grave. Additional types of messages include critical remarks about the behavior of the bereaved. However, these research findings indicate that such messages rarely led relatives to take action. Nevertheless it is important to consider that dream narrations of this particular kind were kept within the limits of strictly private talk; people were rather reluctant to tell me about them.

\section{RELIGIOUS DISCOURSE ABOUT DREAMS IN THE LOCAL COMMUNITY}

Since 1989, religious literature has been distributed in the locality more widely in comparison with the communist period. One such publication is Prekvapujúce tajomstvo duši v ocistci (Astonishing Mystery of the Souls in Purgatory, undated), with the story of an Austrian villager named Maria Simma. This woman had been able to communicate with souls in purgatory since her youth. She could convey messages to their relatives and help souls on their road to salvation through her prayers. Maria Simma claimed that she could communicate with souls in purgatory while she was awake and conscious; thus her communication with the dead was not necessarily dreams or visions. The book also contains Maria Simma's opinions on purgatory, helping the dead, sins leading to purgatory, and mortal sins. The second part of the book tells about the ideas of Saint Padre Pio, Saint Thérèse de Lisieux, and Saint Faustína Kowalská regarding purgatory and means of helping dying people or the souls of the dead. The book's conclusion includes prayers for the dead and ways of obtaining indulgences (participation in church services or stations of the cross, reading the Bible, etc.). The publications Astonishing Mystery of the Souls in Purgatory and the Diary of Saint Faustína (Kowalská 2003) were read by believers in the church after evening services. Many of my female informants know or own these books.

The Catholic priest serving during my research in 2007 and 2008 was a young educated man. He was teaching at the Faculty of Theology of Comenius University in Bratislava and was specializing in eschatology, among other topics. He used his 
scholarly knowledge during his tenure. During the most recent research period on the occasion of a funeral he delivered a remarkably interesting sermon on the afterlife and the souls of the dead.

The priest tolerated the parishioners' dreams and referred to the present open attitude of the church towards such phenomena. According to him, the Holy Scripture shows that God announced his will to people in dreams many times. Among several examples of such prophetic dreams, he mentioned Joseph's dream about an angel that announced he could return home from Egypt together with his family. The priest assumed that God could use dreams as a way to demonstrate His will.

When someone told the priest a dream about the dead, he evaluated it primarily as a natural psychological phenomenon. He assumed that such dreams help people deal with the loss of their loved ones. However, when the parishioners said that they dreamed about the dead, he did not automatically relate those dreams to the belief in purgatory. The priest did not support the opinion that the souls of the dead could visit the living and establish contact with them. On the other hand, he presumed that a connection between the living and the dead exists and that communication between them is possible. However, this happens in a conscious state, not while dreaming. This means that the souls of the dead, angels, or fallen angels (i.e., demons) could appear to people. Because people cannot see souls or angels, these beings have to attract attention by sounds or touches, or they have to take human form. It is an apparition, the establishment of a contact in a waking state, but not in a dream. According to the priest, the Catholic Church distinguishes between dreams and such apparitions, and the two should not be mixed.

However, at the end of our talk the priest recalled the dream of St. Faustína described in her diary. The saint could not deal with some of her problems and prayed to St. Thérèse de Lisieux for help. After three days of prayers, St. Thérèse appeared to her in a dream and told her that she would solve the problems; indeed, this later happened. St. Faustína concluded the description of her dream with the words: "They say you should not believe in dreams, but in God. . . It was a dream, but it was meaningful" (Kowalská 2003: 103-104). According to the priest, St. Faustína’s statement reflects the present attitude of the Catholic Church towards dreams: it is a cautious stance acknowledging that under certain conditions dreams could be meaningful and might convey messages from God or the saints.

The opinions of the priest as a local representative of the church created an appropriate framework for dream narrations. The informants repeatedly mentioned passages from the priest's sermons as well as religious literature. While interpreting dreams about the dead, they sometimes referred to the book about Maria Simma: they assumed that her story was an argument for the existence of a connection between the dead and the living. However, they overlooked the fact that they communicated with the dead in dreams, whereas the souls appeared to Maria Simma when she was fully awake. 


\section{SOCIAL DISCOURSE ABOUT DREAMS IN SLOVAKIA AND DREAM NARRATIONS IN THE LOCAL COMMUNITY}

Soon after the political changes of 1989, the inhabitants of Závod might have followed discussions concerning death and dying, existence of the afterlife, dreams and dreaming, and other previously taboo issues that started to appear in newspapers and magazines, on TV and radio, and in other mass media. At present, for instance, women watch Osudom skúšani (Tried by Fate), a regular TV show on the public channel Slovak Television 1. The show is dedicated in particular to invalids and people that are mortally ill or are suffering from serious illnesses. Attention is also paid to unusual "supernatural" events; for instance, "miraculous" healing or unexplained phenomena (dreams, apparitions, etc.) interpreted as signs of death or, conversely, healing and life. Pošta pre Teba (Mail for You) belongs to the same type of TV shows. It is broadcast on Slovak Television 1 during prime time, every Friday about eight o'clock in the evening. The show's website describes it as a "program about meetings of people that have had something to say to each other and finally found the courage to do it. Viewers can witness the strong emotions, crucial moments, and genuine feelings of people that meet in the TV studio in Bratislava in front of cameras." The stories presented there are often related to extreme situations, experience with death in family, and similar issues.

TV shows, radio broadcasts, and articles in press have resulted in significant changes in the social discourse in comparison with the situation before 1989. When my informants described their experience with dreams about the dead, sometimes they referred to the stories they knew from the mass media; for instance, from public Slovak Television. Those sources enforced their beliefs regarding contact between the living and the dead in dreams.

\section{CONCLUSION}

Dream narratives about the dead present a consistent and important part of everyday communication in Závod. Usually they are confined to private talks, but in some circumstances the boundary between private and public talks is rather fuzzy. In some specific cases, narrators may even deliberately try to promote their dream narratives in public talk to give the community important messages about family affairs that for some reason became public events.

Descriptions and interpretations of dreams mostly belong to women's activities. Men usually express reserved attitudes towards dreams about the dead and perceive them as odd experiences. They seldom talk about such dreams or interpret them. If a

9 http://www.stv.sk/relacieaz/jednotka/posta-pre-teba/, accessed 29 December 2008. 
message from the dead communicated in a dream requires some action, this is mostly performed by women (prayers, requesting a mass for the dead, giving alms, mending family relationships, etc.).

The findings presented here demonstrate that dream narratives are told mostly by women either to other women or to a mixed audience. Representations of dreams as a communication method between the living and the dead do not depend on women's education, age, or social position. They are instead related to the vigor of their Christian faith (concepts of the souls, heaven, hell, and purgatory) and to their interest in various supernatural phenomena that have been intensively discussed in the press, on TV and radio, and so on. Men rarely talk about dreams. They do so within the framework of private talk in the family circle. Unlike women, men usually doubt in the possibility of establishing a connection between the living and the dead in dreams.

This research has demonstrated that narration of dreams within the framework of private talk has been continually practiced in Závod for a long time. However, it is possible to observe a certain change in the second half of the twentieth century corresponding to the difference between the communist period and the present situation. This difference is related to the changes in social discourse in Slovakia, offering new possibilities to transmit and maintain interpretations of dreams that were conveyed almost exclusively by oral tradition in the past.

\section{REFERENCES}

Edgar, Ian

2000 Cultural Dreaming or Dreaming Cultures? The Anthropologist and the Dream. Zeitschrift für Kulturwissenschaften 13 (Träume/n): 1-20.

Hasan-Rokem, Galit

1999 Communication with the Dead in Jewish Dream Culture. In: Shulman, David and Guy G. Stroumsa (eds.), Dream Cultures: Explorations in the Comparative History of Dreaming. Oxford \& New York: Oxford University Press, 213-232.

Herdt, Gilbert

1987 Selfhood and Discourse in Sambia Dream Sharing. In: Tedlock, Barbara (ed.), Dreaming: Anthropological and Psychological Interpretations. Cambridge: Cambridge University Press, 55-85.

Jamnická, Vilma

2001 Sny a videnia. [Dreams and Visions] Bratislava: Ikar.

Jendrej, M.C.

1992 Ingessana Dreaming. In: Jendrej, M. C. and Rosalind Shaw (eds.), Dreaming, Religion and Society in Africa. Studies on Religion in Africa VI. Leiden, New York and Köln: E. J. Brill, 101-125.

Kowalská, Faustína

2003 Denníček. Božie milosrdenstvo v mojej duši. [Diary: Divine Mercy in My Soul] Smižany: Spoločnost’ katolíckeho apoštolátu Palloti.

Krátky, Radovan

1969 Snár. Najnovši egyptsko-perzsko-chaldejsko-československý obsahujúci vysvetlenia v̌̌etkých snov podla 
najosvedčenejšich a najvyskúšanejších prameňov. [The Newest Egyptian-Persian-Chaldean-Czechoslovakian Book on Dream Interpretation Encompassing Explanations of All Dreams According to the Most Reliable and Tested Sources] Bratislava: Smena.

Lipták, Lubomír

2000 The Communist Model of Industrialization and Modernization. In: Mannová, Elena (ed.), A Concise History of Slovakia. Bratislava: Historický ústav SAV and Academic Electronic Press, 284-286.

Mannová, Elena and Roman Holec

2000 On the Road to Modernization 1848 - 1918. In: Mannová, Elena (ed.), A Concise History of Slovakia. Bratislava: Historický ústav SAV and Academic Electronic Press, 185-234.

Martin, Dominique

1999 Modernization in the Crisis: From Talcott Parsons to Jürgen Habermas. In: Adamski, Wladyslaw W. et al. (eds.), System Change and Modernization: East-West in Comparative Perspective. Warsaw: IfiS Publishers, 23-44.

Miller, Daniel

1995 Introduction. In: Miller, Daniel (ed.), Worlds Apard: Modernity through the Prism of the Local. London and New York: Routledge, 1-21.

Podolinská, Tatiana

2010 The Religious Landscape in Post-communist Slovakia. Anthropological Journal of European Culture 19 (1): 85-101.

Pócs, Eva

1999 Between the Living and the Dead: A Perspective on Witches and Seers in the Early Modern Age. Budapest: Central European University Press.

Prekvapujúce tajomstvo dušiv ocistci

Undated [Astonishing Mystery of the Souls in Purgatory] Bratislava: Magnificat Slovakia.

Shaw, Rosalind

1992 Dreaming as Accomplishment: Power, the Individual and Temne Divination. In: Jendrej, M. C. and Rosalind Shaw (eds.), Dreaming, Religion and Society in Africa: Studies on Religion in Africa VI. Leiden, New York and Köln: E. J. Brill, 36-54.

Tedlock, Barbara

2003 The New Anthropology of Dreaming. In: Harvey, Graham (ed.), Shamanism: A Reader. London and New York: Routledge, 103-122.

Tiukhteneva, S. P.

2007 The Land of My Dreams. Anthropology and Archeology of Eurasia 46 (2): 42-54.

\section{SANJE KOT POSREDNICE KOMUNIKACIJE MED ŽIVIMI IN MRTVIMI: ETNOGRAFSKA ŠTUDIJA PRIMERA S SLOVAŠKE}

Sanje o pokojnih prednikih, sorodnikih in prijateljih, so posebna kategorija sanjskih izkušenj $v$ evropskih in neevropskih družbah. Raziskave so pokazale, da so pogoste. V različnih kulturah so sanje o prednikih ali pokojnih sorodnikih sprejete kot način komunikacije med živimi in mrtvimi, posredujejo sporočila, opozorila ali razlage, ali pa so prošnje za pomoč. Razprava se osredinja na sanjske pripovedi o pokojnih in na proces pripovedovanja in 
posredovanja v skupnosti na Slovaškem. Avtorica sanjske pripovedi razume kot zgodbe, ki navadno sporočajo tako vsebino sanj kakor njihovo interpretacijo in "implementacijo”. To pomeni, da sanjske pripovedi lahko povedo kaj o dogodkih, ki so sledili sanjam, o uresničenih ali neuresničenih napovedih ali o implikacijah sanj za tistega, ki sanja, pa tudi za njegovo družino, prijatelje ali sorodnike.

Med raziskavo si je avtorica prizadevala, da sanjske pripovedi pridobi kot ustne zgodbe. Poleg tega pa jo je zanimal proces pripovedovanja, in zaradi tega se je posvetila tudi načinom razširjanja sanjskih izkušenj. Prav tako je preučila prenos pripovedi v lokalni skupnosti, povezano z socialnim kontekstom: pozorna je bila na pripovedovalca in poslušalstvo, upoštevaje socialne skupine v kraju.

Ugotovila je, da so bile sanjske pripovedi o pokojnih konsistenten in pomemben del vsakdanje komunikacije v kraju. Navadno so bile omejene na zasebne pogovore, v nekaterih okolišcinah pa je bila meja med zasebnim in javnim pogovorom precej zamegljena. V prav posebnih primerih so si pripovedovalci celo prizadevali javnosti posredovati svoje sanjske pripovedi, da bi skupnosti predali pomembna sporočila o družinskih zadevah, ki so postale javni dogodki.

Opisi in interpretacije sanj sodijo pretežno med ženske dejavnosti. Moški navadno izražajo pridržke do sanj o pokojnih in jih imajo za čudaške izkušnje. Redko govorijo o sanjah ali jih razlagajo. Č je sporočilo pokojnika v sanjah zahtevalo kak ukrep, so ga v veliki meri izpeljale ženske (prošnje, naročilo maše za pokojnega, dajanje miloščine, krpanje družinskih odnosov itn.).

Raziskava je pokazala, da so o sanjskih pripovedih pripovedovale večinoma ženske - bodisi ženskam ali mešanemu poslušalstvu. Reprezentacije sanj kot način sporazumevanja med živimi in mrtvimi niso odvisne od izobrazbe, starosti ali družbenega položaja pripovedovalk. Bolj jih je mogoče povezati z njihovo gorečnostjo do krščanske vere (koncepti duše, nebes, pekla in vic) in interesom za različne nadnaravne pojave, o katerih se intenzivno govori v tisku, na televiziji, po radiu itn. Moški o sanjah govorijo zelo redko; če pa, le zasebno v družinskem krogu. Nasprotno ženskam moški navadno dvomijo o možnosti, da bi $v$ sanjah postavili stik med mrtvimi in živimi.

Raziskava je tudi pokazala, da je pripovedovanje o sanjah v zasebnih pogovorih že dolgo stalna lokalna praksa. Je pa bilo mogoče opaziti določeno spremembo v drugi polovici 20. stoletja, ki ustreza razločku med socialističnim obdobjem in trenutnim položajem. Razloček je povezan s spremembami $v$ družbenem diskurzu na Slovaškem, ki omogoča nove načine sporočanja in razlag sanj, ki so bili v preteklosti posredovani izključno z ustnim izročilom.

PhDr. Gabriela Kiliánova, CSc., Institute of Ethnology, Slovak Academy of Sciences, Klemensova 19, 81364 Bratislava, Slovaška, gabriela.kilianova@savba.sk 
